\title{
Stafræn tækni í leikskólastarfi: Sjónarhorn frumkvöðla
}

\author{
Anna Elísa Hreiðarsdóttir
}

$\checkmark$ Abstract Um höfund $\rightarrow$ About the author $\rightarrow$ Heimildir

Snjalltækni hefur orðið hluti af daglegu lífi fólks og sífellt yngri börn hafa greiðari aðgang að henni. Skólar hafa væðst pessari nýju tækni og henni er ætlað að vera hluti af starfi leikskóla (Mennta- og menningarmálaráðuneytið, 2011). Á sama tíma takast á sjónarmið um gagnsemi eða skaðsemi tækninnar í lífi og námi ungra barna. Rannsóknir eru dregnar fram sem sýna bæði jákvæð áhrif tækninnar á nám ungra barna sem og takmarkanir eða jafnvel skaðsemi. Einnig er horft til reynslu leikskóla af stafrænni tækni síðustu tvo áratugi pví tölvur voru pegar páttur í starfi sumra leikskóla undir síðustu aldamót og í fyrstu ađalnámskrá leikskóla (Menntamálaráðuneytið, 1999) var kveðið á um að tölvur skyldu vera hluti af búnaði peirra. Markmið greinarinnar er að varpa ljósi á reynslu frumkvöðla af tæknivæðingu íslenskra leikskóla fyrr og nú, viðhorf peirra og sýn á pátt stafrænnar tækni í starfi leikskóla. Tekin voru einstaklingsviðtöl við sjö frumkvöðla í innleiðingu tölva og tækni í leikskóla, frumkvöðla sem allir voru að störfum fyrir útkomu aðalnámskrár árið 1999 og í kjölfar hennar. Allir eiga pað sameiginlegt að vera leikskólakennarar og vinna enn með tölvur og tækni í leikskólastarfi. Niðurstöður sýna að mikil og löng reynsla liggur að baki tölvuvæðingu leikskóla og á peim árum sem liðin eru síðan fyrstu leikskólarnir tæknivæddust hafa frumkvöðlarnir ekki kvikað frá peirri trú að tæknin geti eflt nám barna og hana megi nýta með margvíslegum hætti í leikskólastarfi. Róðurinn hefur lengst af verið pungur, sérstaklega í upphafi, enn virðist erfitt að fá nægilegan búnað eða rétta búnaðinn. Kennararnir eru gagnrýnir á ytra umhverfi leikskóla og segja að draga mætti meiri lærdóm af pví sem pegar hefur áunnist á sviði tækni í leikskólum. Einnig telja peir að stundum skorti markvissa úthlutun og innleiðingu par sem bjargir séu tryggðar. Deir leggja áherslu á markvissa, skapandi og sampætta notkun tækninnar, bæði í aðferðum og viðfangsefnum, vilja nota fjölbreytta kennsluhætti og reyna nýjar leiðir í kennslu.

Efnisorð: Leikskólar, tölvur, stafræn tækni, frumkvöðlar

\section{Inngangur}

Árið 1999 urðu vatnaskil í íslenskri leikskólasögu pegar fyrsta aðalnámskrá leikskóla tók gildi en fram að pví höfðu leikskólar starfað eftir uppeldisáætlunum (Menntamálaráđuneytið, 1985, 1993). Sitthvað bar nýtt við í aðalnámskránni og pá ekki síst að einn kaflinn bar heitið Tölvur og lýsti peirri stefnu stjórnvalda að tölvur skyldu verða hluti af búnaði leikskóla. Rökin sem færð voru í kaflanum voru pessi: „Barn í leikskóla parf að kynnast tölvu og læra að nota hana á sinn hátt“ (Menntamálaráðuneytið, 1999). Gefnar voru leiðbeiningar um hvar koma mætti tölvubúnaði fyrir, sem og um val á forritum. Megintilgangurinn var að jafna uppeldisskilyrði barna með peim hætti að börn sem ekki höfðu aðgang að tölvum heima gætu kynnst peim í skólanum. 
Degar aðalnámskráin tók gildi höfðu fáeinir leikskólar pegar stigið fyrstu skrefin með tölvur í námi og kennslu og í kjölfarið tóku fleiri skólar tölvur inn sem hluta af leik- og kennsluefni barnanna. Anna Magnea Hreinsdóttir, Kristín Norðdahl og Svala Jónsdóttir (2005) segja að í leikskólanum Iðavelli á Akureyri hafi tölvur verið leikefni allt frá árinu 1997 pegar foreldrar söfnuðu fé svo kaupa mætti fyrstu stafrænu tækin til nota með börnunum. Leikskólarnir á Seltjarnarnesi; Sólbrekka og Mánabrekka, unnu að próunarverkefni veturinn 1998-1999 á tölvur sem fyrirtæki hafði gefið skólanum. Verkefnið var styrkt af Sprotasjóði sem hefur í gegnum árin styrkt nokkur verkefni um tölvur og tækni í leikskólum. Árið 1999 hélt menntamálaráðuneytið ráđstefnu undir heitinu UT99 par sem Guðrún Alda Harðardóttir, Kristín Dýrfjörð og Hrafnhildur Konný Hákonardóttir fluttu erindi um upplýsingatækni í leikskólastarfi (Dagskrá UT99, 1999). Đá má nefna að hópur leikskólabarna var á meðal nemendahópa sem komu fram í Kennslustofu framtíðar sem haldin var á ráđstefnunni og sátu par við práđlausar fartölvur (Torfi Hjartarson, 1999). Til ársins 2006 voru UT-ráđstefnur árviss viðburður og á flestum peirra voru erindi frá leikskólum. Árið 2001 vann leikskólinn Funaborg í Reykjavík að verkefni um samskipti par sem tölvur komu við sögu. Ári síðar voru leikskólinn Klappir á Akureyri að vinna með upplýsingatækni í starfinu með börnunum og skólar Hjallastefnunnar að próa vef til að efla samskipti við foreldra. Íslenskur vefur um vísindanám leikskólabarna hlaut síðan priðju verðlaun evrópska skólanetsins árið 2003 (Akureyrarbær, 2003). Rétt er að geta pess að höfundur er annar höfundanna að peim vef og var á sínum tíma einn af frumkvöðlunum í leikskólastarfinu á Iðavelli.

Fyrsta íslenska rannsóknin á pessu sviði er líklega rannsókn Guðrúnar Öldu Harðardóttur (2001) á tölvu sem viðfangsefni barna í leik. Gagnaöflun fór fram árið 1998 í leikskólanum Kiðagili á Akureyri. Árið 2002 hófst síðan viðamikil rannsókn á notkun upplýsingatækni á öllum skólastigum og bar hún heitið NámUST. Einn hluti rannsóknarinnar sneri að leikskólum og náði til sex leikskóla sem vitað var að höfðu unnið með tölvur í skólastarfinu og var áherslan á viðtöl við kennara (Anna Magnea Hreinsdóttir, 2004; Kristín Norðdahl og Svala Jónsdóttir, 2005). Einnig voru gerðar prjár stuttar heimildamyndir um starfið í leikskólanum Iðavelli á Akureyri (Karl Jeppesen og Svala Jónsdóttir, 2006a, 2006b, 2006c). Niðurstöður sýna að leikskólar fóru ólíkar leiðir, starfsfólk var almennt jákvætt en markviss stefna og stuðningur skipti máli. Tölvur voru notaðar á margvíslegan máta, til náms, samskipta og afpreyingar. Bakgrunnur, pekking og áhugasvið kennara höfðu mikil áhrif og aðferðir tengdust áherslum skólanna. Oft lá árangur í vinnuframlagi einstakra kennara sem drifu starfið áfram. Síðan pá hefur lítið verið um rannsóknir á tölvutækni í leikskóla en skólar hafa tekið pátt í fjölmörgum próunar- og samstarfsverkefnum, svo sem Comeniusar-, Erasmus+- og eTwinning-verkefnum og sumir hlotið viðurkenningu fyrir (t.d. Erasmus+, e.d., 2016). Á síðustu árum hafa sveitarfélög tekið að setja stefnu eða viðmið um notkun snjallækja í leikskólum á peirra vegum (s.s. Kópavogsbær, 2013) og skrifaðar hafa verið skýrslur um upplýsingatækni í leikskólastarfi (t.d. Capacent, 2014; Skóla- og frístundasvið Reykjavíkurborgar, 2017). Leikskólar hafa einnig unnið próunarverkefni tengd tölvutækni (Miðstöð skólapróunar, e.d.) pó misjafnt sé hvort verkefnin snúi að kennurum eða starfinu með börnunum og Fjóla Dorvaldsdóttir (2018) heldur úti vef um upplýsingatækni fyrir kennara yngri barna sem var hluti af meistaraverkefni hennar. Ísland er um pessar mundir aðili að evrópskri rannsókn sem ýta á undir tæknilæsi 0-8 ára barna (Lahmar o.fl., 2017) og pá hafa Reykjavíkurborg og Háskóli Íslands átt í samstarfi við norræna leikskóla og kennaramenntunarstofnanir um próun og rannsóknir á notkun spjaldtölva í leikskólastarfi (Torfi Hjartarson og Svava Pétursdóttir, í prentun). Ljóst er að notkun stafrænnar tækni er ekki nýtt fyrirbrigði í starfi leikskóla og mikilvægt að halda sögunni til haga, ekki síst með pað аð markmiði að læra af henni.

Samkvæmt niðurstöðum Kjartans Ólafssonar, Livingstone og Haddon (2014) fækkar evrópskum rannsóknum um stafræna tækni í lífi og leik barna eftir pví sem börnin eru yngri og verulega fáar rannsóknir tengjast börnum yngri en priggja ára. Flestar rannsóknir snúast um aðgengi og notkun og ljóst að skortur er á rannsóknum á flestum hliðum tölvunotkunar í íslenskum leikskólum. Dví má taka undir orð Holloway, Green og Livingstone (2013) sem segja að aldrei hafi verið meiri pörf á upplýsingum um tæknihegðun yngstu samfélagspegnanna. Hsin, Li og Tsai (2014) tóku saman yfirlit yfir rannsóknir á tækninotkun ungra barna sem birtust á tímabilinu 2003-2013 í 
alpjóðlegum tímaritum og fundu að rannsóknaráherslur voru helst á prennt; gagnsemi tækninnar, hlutverk fullorðinna og kennsluaðferðir. Öðru hefur verið minna sinnt og sem dæmi má nefna að skortur er á rannsóknum á skapandi notkun tölvutækni í skólum.

Nú eru liðin ríflega tuttugu ár síðan tölvur komu í fyrstu leikskólana sem hluti af náms- og leikefni barnanna, tímabil sem hófst með innleiðingu tölva í starfi með börnum í leikskóla í kringum útkomu Aðalnámskrár leikskóla 1999 (Menntamálaráđuneytið, 1999) og spannar tímann fram yfir tilkomu snjalltækninnar síðustu misserin. Í rannsókninni sem hér er greint frá er markmiðið að varpa ljósi á reynslu frumkvöðla af tæknivæðingu íslenskra leikskóla fyrr og nú, auk viðhorfs peirra og sýnar á pátt stafrænnar tækni í starfi leikskóla.

\section{Stafræn tækni í leikskóla}

Snjalltæki eins og spjaldtölvur og snjallsímar eru auðveld í notkun og hafa gert pað að verkum að börn nota stafræn tæki yngri en nokkru sinni fyrr. Livingstone, Görzig og Ólafsson (2011) segja að pví yngri sem börnin eru pví meiri stuðning purfi pau pegar kemur að stafrænu tækninni og Yadav og Chakraborty (2018) benda á mikilvægi pess að snjalltækjanotkun hefur ekki sjálfkrafa jákvæð áhrif á proska ungra barna eða leiðir af sér nám, meira parf að koma til. Fyrrnefndar rannsóknir beinast að tækninotkun barna heima við, jafnvel áður en skólaganga hefst og sýna að börn hafa snjalltæki í höndunum frá unga aldri. Á hinn bóginn er einnig ljóst að rannsóknir tengdar börnum og snjalltækjum beinast helst að unglingum og eldri börnum en sjaldnar að yngri börnum og fáar að allra yngstu börnunum (Kjartan Ólafsson, Livingstone og Haddon, 2014). Dekking á pessu sviði hefur pó aukisten enn má greina togstreitu og andstæð sjónarmið í umræðunni, svo sem pau að snjalltæknin sé annars vegar ýmist varasöm eða beinlínis hættuleg ungum börnum og hins vegar að hún sé peim nánast eðlislæg (Plowman og McPake, 2013) og nauðsynleg til náms og proska í nútíma samfélagi (Hsin, Li og Tsai, 2014). Aðrir telja að ekki liggi fyrir rannsóknir sem sýni með óyggjandi hætti að snjalltæknin bæti námsárangur ungra barna (Dhir, Gahwaji og Nyman, 2013). Ernest, Causey, Newton, Sharkins, Summerlin og Albaiz (2014) segja helst tekist á um pað í umræðunni um tölvur í leikskólanum hvort tölvur hafi jafnvel slæm áhrif á nám og proska barnanna og pá sérstaklega á félagsproska. Rannsóknir sem sýna jákvæðar hliðar tölvutækni á börn á leikskólaaldri eru pó mýmargar (s.s. Marsh, 2010; Hsin o.fl., 2014) og færð eru rök fyrir pví að tölvutæknin geti að auki verið leið til að valdefla börn og auðvelda peim pátttöku í samfélaginu (Lindahl og Folkesson, 2012).

Félagsproski er mikilvæg forsenda pess að fóta sig í lífi og leik sem rétt er að staldra við og skoða sérstaklega í ljósi pess sem fram hefur komið hér að framan. Minna parf á rannsóknir sem sýna að stafræn tækni getur haft jákvæð áhrif á félagsproska (Hsin o.fl., 2014) og samskipti (Marsh, 2010), fyrst og fremst vegna pess að félagsproski er mikilvægt veganesti inn í framtíð hvers einstaklings og svo hins, að sú trú er lífseig að tölvur vinni gegn félagsproska (Plowman og McPake, 2013). Rannsóknir á áhrifum snjalltækni í skólastarfi á nám og proska tengjast gjarnan fleiri en einum proskapætti og benda oft til jákvæðra áhrifa á félagsproska (s.s. Fessakis, Gouli og Mavroudi, 2013). Slíkar rannsóknir beinast ekki síst að málproska í námi og proska leikskólabarna og niðurstöður sýna jákvæða fylgni milli tölvutækni í skólastarfi og framfara barnanna hvað hann varðar (s.s. Broemmel, Moran og Wooten, 2015; Hoffman og Paciga, 2014). Rannsóknir hafa einnig sýnt pau áhrif mælanleg til langframa (Segers og Verhoeven, 2005). Hins vegar minna Neumann og Neumann (2014) á að námsárangurinn helst í hendur við gæði forrita og pann stuðning sem kennarar veita börnum meðan unnið er í tölvunum. Einnig parf að hafa í huga að leikskólabörn vinna flest betur í samvinnu við önnur börn og hafa jafnvel meira úthald en pegar peim er ætlað að vinna ein og sér (Butler og Walton, 2013).

Yilmaz (2015) segir að til að nám eigi sér stað purfi samskipti við tæknivinnu og gagnvirkni forrita. Cristia og Seidl (2015) leggja áherslu á að vanda purfi til viðfangsefna sem unnin eru í tölvunum og að sama skapi purfi forrit sem miða að námi og proska að vera gagnvirk og gera 
ráð fyrir fleiri en einni lausn. Orrin og Olcese (2011) segja að vandað námsforrit purfi að bjóða upp á samvinnu, byggja á lausnaleit og efla sköpun. Mörg námsforrit fyrir yngstu börnin virðast ekki standa nógu vel undir pessum kröfum og bví mikilvægt að kennarar vandi val á forritum. Edwards (2013) minnir á að vinna parf með gagnrýna hugsun barnanna samhliða vinnu með tölvutækni ef vel á að vera. Pá hafa fræðimenn einnig tekist á um hvort tölvutæknin sé í andstöðu við hugmyndir um nám í gegnum leik. Palmer (2015) heldur pví fram að notkun tölvu falli ekki undir skilgreiningar á leik og pví séu börn í kennslufræðilegum skilningi ekki að leika sér pegar pau eru í tölvunni. Í ljósi pess að í leikskóla er leikurinn námsleið barnanna skipta sjónarmið sem pessi máli og parfnast umræðu. Pannig má benda á að Marsh (2010) kemst að peirri niðurstöðu að snjalltæknin geti vakið leikgleði barnanna og Marsh, Plowman, Yamada-Rice, Bishop og Scott (2016) segja að snjalltæknin dragi ekki endilega úr mikilvægi leiksins heldur hafi hún áhrif á eðli hans og inntak. Leikurinn eigi sér stað í snjalltækinu og utan pess og flæði par á milli sé nokkuð viðstöðulaust, leikurinn fer pá fram með hætti sem ekki væri mögulegur án tækninnar. Tölvutæknin er par með orðin hluti af og viðbót við leik barnanna. Nikolopoulou og Gialamas (2015) hafa einnig bent á að pegar börn vinni í og með stafræna tækni gefi pað peim færi á að leika sér um leið og pau læra en Edwards (2013) segir enn skorta sýn á að tölvutæknin og leikmiðaðar kennsluaðferðir geti farið saman. Mikilvægt sé að efla skilning á möguleikum tækninnar sem náms- og leikefnis leikskólabarna.

Niðurstöður rannsókna hafa sýnt fram á tengsl notkunar á snjalltækni í skólastarfi við árangur og framfarir barnanna á fleiri sviðum. Dannig getur stafræn sögugerð skilað meiri árangri en hefðbundnari leiðir í stærðfræðinámi ungra barna (Preradovic, Lesin og Voras, 2016), teikniproski barna eflst og börnin sýnt greinanlega meiri áhuga og úthald við stafræn verkefni (Couse og Chen, 2014). Stafræn tækni í leikskólastarfi getur líka eflt gagnrýna hugsun barnanna (Shawareb, 2011). Dá er mikilvægt að draga fram rannsóknir sem sýna að tölvur geta unnið gegn aðstöðumun barnanna, svo sem rannsókn McKenney og Voogt (2010), en par kom fram að börn með félagslega veikari bakgrunn höfðu jákvæðara viðhorf og sóttu meira í tölvurnar en börn úr millistétt. Dietze og Kashin (2013) segja að leikskólakennarar geti lagað stafrænu tæknina að uppeldisfræði skólans og skapað aðstæður sem efla nám og leik barnanna. Dær draga pann lærdóm af rannsókn sinni að samræða samkennara sé farsæl leið til að ná árangri. Ernest o.fl. (2014) hafa einnig bent á að ígrundun og aukinn skilningur á möguleikum tækninnar sé aðferð til að takast á við efasemdaraddir og í kjölfarið megi finna leiðir sem skila árangri og innleiða pær í starf leikskóla. Á hinn bóginn er vert að nefna að kennarar eru gagnrýnir og sjá tækifærin sem snjalltæknin býður upp á án pess að vera blindir á takmarkanir tækninnar (Wood, Specht, Willoughby og Mueller, 2008).

Snjalltæknin er hluti af menningu leikskólabarna og tæknin pykir komin til að vera (Holloway o.fl., 2013). Palaiologou (2016) bendir á að snjalltæki leiki nú pegar stórt hlutverk í lífi flestra barna og pað kalli á að kennarar endurskoði hugmyndir sínar um hvernig börn læra og hvernig námsumhverfi peirra er skipulagt. Ertmer og Ottenbreit-Leftwich (2013) segja mikilvægt að líta á snjalltæknina sem leið að námsmarkmiðum en ekki markmið í sjálfu sér. Tæknin sé pá tæki til að vinna að námi og proska, leiktæki eða kennslugagn.

\section{Tölvutæknin og kennarar}

Nilsen, Lundin, Wallerstedt og Pramling (2018) komast að pvíí rannsókn sinni að leikskólakennarar eigi til að nota stafræna tækni til að fara hefðbundnar leiðir á meðan rannsóknir sýna að börnin nota stafrænar útgáfur kennsluefnis og leikja með öðrum hætti en pær hefðbundnu. Masoumi (2015) tekur undir petta og segir tæknina gjarnan notaða til að gera pað sama og áður í stað pess að gera nýja hluti og efla pannig námstækifæri barnanna. Fleiri rannsakendur hafa komist að sömu niðurstöðu (s.s. Lynch og Redpath, 2014; Yurt og Cevher-Kalburan, 2011). Lindahl og Folkesson (2012) segja suma kennara fylgjandi pví að nota tölvutækni í starfi leikskólans en aðra hafa um hana efasemdir. Dví kennslu- og tölvutæknireyndari sem kennarinn er, pví líklegra er að hann telji að leikur í tölvu geti haft margvíslegt gildi. Samt sem áður nota sömu kennarar tæknina 
minna með börnunum en við skipulag og undirbúning starfsins (Nikolopoulou og Gialamas, 2015). Masoumi (2015) tekur í sama streng og segir kennara nota tölvur til skráninga og sem tæki til að efla menntun barnanna en vill meina að líkur séu á að viðfangsefnin séu hin sömu og áđur sem vekur spurningar um hvernig hægt sé að færa kennurum víðari sýn á tækifærin sem fylgja snjalltækninni, meðal annars til að auka fjölbreytileika í námi og aðferðum.

Rannsakendur hafa í auknum mæli beint sjónum að viðhorfum kennara til stafrænnar tækni sem viðfangs eða verkfæris í námi yngri barna (Preradovic o.fl., 2016). Konca, Ozel og Zelyurt (2016) segja pau almennt jákvæð og að kennarar líti svo á að tölvutæknin sé mikilvægur páttur í leikskólastarfi. Deir virðast pó margir hverjir uppteknari af pví hvað tæknin geti gert börnum fremur en hvað hún geti gert fyrir börnin (s.s. Hoffman, Park og Lin, 2015; Masoumi, 2015; Nikolopoulou og Gialamas, 2015). Bird og Edwards (2015) telja að til að leikskólakennarar meti tölvutæknina að fullu purfi peir að sjá uppeldisfræðilegt gildi hennar í leikskólastarfi sem byggir á námi í gegnum leik. Ef ætlunin er að efla snjalltækjanotkun í leikskólastarfi er pví mikilvægt að sýna kennurum fram á jákvæð tengsl tækninotkunar við námsárangur og proska sem spretta af leikmiðuðum kennsluaðferðum. Annar mikilvægur páttur er markviss notkun tölvutækninnar og Northrop og Killeen (2013) benda á að snjalltæknin leiði ekki sjálfkrafa af sér nám heldur sé nauðsynlegt að ramma kennslufræðina inn og vera vakandi fyrir pví að raunverulegt nám fari fram, fremur en pví að börnin séu að nota tæknina handahófskennt eða af litlum skilningi og mismikilli færni. Kennarar leika pví veigamikið hlutverk pegar taka á tæknina í notkun, peir purfa að nýta hana með peim hætti að börnin læri og fylgjast með eða greina hvað pau læra í gegnum vinnu og leik við tölvur og tæki.

Hoffman o.fl.(2015) benda á að í stað pess að spyrja hvort megi nota tölvutækni, eigi að spyrja hvernig hægt sé að styðja kennara í að nota tæknina, gefa peim tæki, pekkingu og leiðir til að bregðast við örri tæknipróun. Rannsóknir hafa sýnt tiltekna pætti sem helst hindra notkun tölvutækni í leikskólastarfi. Sem dæmi greinir Liu (2015) tvo pröskulda í veginum, sá fyrri felst í skorti á tækjum og vélbúnaði, skorti á efni fyrir kennara og kennsluefni og pörf fyrir uppeldisfræðilega sýn á möguleika sem tæknin veitir. Seinni pröskuldinn segir hún felast í áhugaleysi kennara eða skorti á stuðningi. Vu (2015) tekur undir petta og telur tvennt standa notkun á snjalltækjum í kennslu fyrir prifum, annars vegar að kennarar hafi litla pjálfun í að nota snjalltæki í kennslu og hins vegar að skóla skorti gjarnan fjármagn til að kaupa og reka tölvur og tæki. Skortur á fjármunum er nefndur sem hindrun í niðurstöðum fleiri rannsókna (s.s. Thorpe o.fl., 2015) en helstu hindranir sem kennarar sjálfir nefna eru tímaleysi, álag, breytingar í starfsmannahaldi og skortur á stuðningi stjórnenda (Cherrington o.fl., 2009). Kennarar hafa almennt áhuga á að nota tölvutækni í starfi með börnunum en helstu hindranir virðast pær að pá skorti pekkingu á pessu sviði og að peir hafi par með ekki næga trú á eigin hæfni. Aðrar rannsóknir nefna skort á stuðningi og nauðsynlegum björgum sem helsta vandann sem kennarar standa frammi fyrir í vinnu með tölvutækni í leikskólum (s.s. Blackwell, Lauricella og Wartella, 2014; Bingimlas, 2009). Hindranir felast með öðrum orðum í að skólana skortir fjármagn til að kaupa tæki og reka pau og kennara skortir stuðning, aukna pekkingu og pjálfun. Kerckaert, Vanderlinde og van Braak (2015) segja starfspróun kennara lykilpátt og að hún hafi bein áhrif á hvernig kennarar nýti snjalltæknina í starfi. Chen og Chang (2006) eru á sama máli og telja að starfspróun kennara sé ekki sinnt nægilega, starfspróun sem miði jöfnum höndum að bættum viðhorfum, aukinni færni, pekkingu og framkvæmd.

\section{Aðferð}

Rannsóknin er eigindleg viðtalsrannsókn og byggir á einstaklingsviðtölum enda henta pau vel til að fá vitneskju um reynslu og viðhorf (Helga Jónsdóttir, 2013). Aðferðin fellur pví vel að tilgangi rannsóknarinnar en markmið hennar var að varpa ljósi á reynslu frumkvöðla af tæknivæðingu íslenskra leikskóla fyrr og nú, viðhorf peirra og sýn á pátt stafrænnar tækni í starfi leikskóla. Til að afmarka efnið hvað tæknina varðar voru eftirfarandi skilgreiningar settar sem viðmið. Меð hugtakinu tölva er átt við tölvur af öllum tegundum, sem og snjalltæki, eins og spjaldtölvur og 
lófatölvur (p.m.t. síma og önnur tæki með snertiskjá og netaðgangi). Degar fjallað er um stafræna tækni eða snjalltækni er jöfnum höndum átt við tæki (e. hardware) og forrit (e. software) en einnig ýmiss konar tækni sem tengist tölvunum og notkun jaðartækja.

\section{Pátttakendur}

Pátttakendur voru fundnir með pví að leita uppi pá leikskólakennara sem einnig má kalla frumkvöðla í tölvuvæðingu leikskóla. Leitin að viðmælendum hófst með pví að rannsakandi gróf upp nöfnin á bak við fyrstu próunarverkefnin og erindi á ráđstefnum um tölvur í leikskólastarfi. Viðmælendur purftu að uppfylla prjú skilyrð;; a) að vera leikskólakennari, b) að hafa tekið virkan pátt í að innleiða tölvur í leikskóla pegar pær komu í leikskólana í kringum 1999 og c) að vera enn að í störfum tengdum leikskóla og hafa tekið virkan pátt í snjalltæknivæðingu leikskólastarfs síðustu árin. Í fyrstu yfirferð komu upp nokkur nöfn sem leitað var til um pátttöku og pví er um að ræða markmiðsúrtak (e. purposive sample) sem pýðir að rannsakandi parf að taka ákvarðanir um úrtak í samhengi við markmið rannsóknar (Dórólfur Dórlindsson og Dorlákur Karlsson, 2013). Viðmælendur bentu rannsakanda síðan á aðra sem vert væri að tala við og leitað var til peirra um pátttöku. Úrtak sem valið er með peim hætti kallast snjóboltaúrtak (e. snowball sample). Pannig náðist í sjö viðmælendur sem eru af báðum kynjum og starfa víðs vegar um landið. Peir eru með 25-30 ára starfsreynslu og hafa allir í gegnum árin unnið með tölvutækni og síðar snjalltækni í starfi með leikskólabörnum.

\section{Gagnaöflun og greining gagna}

Saminn var viðtalsrammi fyrir viðtölin, voru spurningar hálfopnar og beindust að reynslu viðmælenda af tölvutækni í leikskólastarfi. Fyrst var spurt um tölvuvæðingu leikskóla um og upp úr árinu 1996 og svo var sambærilegra spurninga spurt um spjaldtölvuvæðingu leikskóla síðustu misserin. Spurt var um viðhorf frumkvöðlanna til tölvutækni í leikskólastarfi, reynslu af innleiðingu tölva og starfinu með tölvutæknina síðustu áratugina. Einnig var spurt um viðfangsefnin sem peir velja að fást við í tækjunum og pá möguleika sem fylgja slíkri vinnu. Leitað var upplýsinga um próunina í notkun tölvutækni í leikskóla og lærdóminn sem af henni má draga í samanburði við væntingar og veruleika pá og nú. Viðfangsefnið var afmarkað við stafræna tækni í leikskólakennslu par sem áherslan er á leikskólafræði og starf með börnum en ekki hvernig kennarar nota tölvutæknina pess utan í starfi sínu. Viðmælendum var bent á í kynningarbréfi að rannsóknin beindist að tölvutækni í starfi með börnunum í víðum skilningi og að par væri átt við fjölbreytta notkun tölvutækni og stafrænna tækja.

Viðtölin voru tekin á vinnustað eða heimili viðmælenda og tóku 60-90 mínútur hvert viðtal. Pau voru hljóðrituð og afrituð áður en pau voru lykluð og pemagreind (Brinkmann og Kvale, 2015). Greining gagna leiddi í ljós sameiginlega pætti í svörum viðmælenda. Í fyrstu úrvinnslu komu skýrt fram tvö sameiginleg pemu, annars vegar um viðhorf kennara til tölvutækninnar og gagnsemi hennar og hins vegar um viðfangsefnin sem peir velja að tengja tækninni. Síðar í úrvinnsluferlinu urðu pemun fleiri; a) fagmennska kennaranna, b) viðhorf til stafrænnar tækni î leikskólastarfi, c) búnaður og bjargir, d) markmið með tölvutækni í leikskólastarfi og e) tölvutæknin í leikskólastarfi.

Sérstök áhersla var lögð á að leita leiða til að tryggja nafnleynd viðmælenda, sérstaklega í framsetningu á niðurstöðum, og pví eru ekki gefnar aðrar bakgrunnsupplýsingar um pá en pær sem liggja að baki pví hvernig peir voru valdir. Frumkvöðlarnir á pessu sviði eru í heildina ekki margir og pví eru gögnin vandmeðfarin en ekki á að vera hægt að pekkja viðmælendur af svörum peirra. Til að koma í veg fyrir að hægt sé að rekja svör til ákveðinna verkefna, sveitarfélaga eða atvika eru svör ekki sundurgreind eftir viðmælendum heldur dregin saman. Pess var einnig gæett að tilgreina ekki kyn peirra sem rætt var við. 


\section{Siðferðilegir pættir og gildi rannsóknarinnar}

Rétt er að hafa í huga nokkur atriði pegar niðurstöður eru skoðaðar. Í fyrsta lagi voru viðmælendur fáir og niðurstöður sýna reynslu peirra og viðhorf en endurspegla ekki sjálfkrafa reynslu eða viðhorf leikskólakennara almennt. Í öðru lagi parf að muna að hér eru ekki endilega dæmigerðir leikskólakennarar að tala heldur frumkvöðlar með mikla reynslu og fagpekkingu á tölvutækni í leikskólastarfi. Í priðja lagi er rannsakandi sjálfur úr hópi frumkvöðlanna á pessu sviði. Allt hefur petta áhrif á niðurstöður og hvernig má túlka pær og rétt að hafa í huga atriði á borð við mögulegan vilja rannsakanda og jafnvel pátttakenda til að hafa áhrif á tæknivæðingu skóla, fjárveitingar og fleira. Hins vegar er einnig mikilvægt að draga fram að rannsókn af pessu tagi er innlegg í umræðu sem er ofarlega á baugi nú um stundir, pað er tölvuvæðing leikskóla og tækninotkun leikskólabarna. Töluverð fjárútlát fylgja pví að tækjavæða skóla og pað skiptir máli að varpa ljósi á hvernig tækin nýtast sem best í námi og starfi leikskólabarna. Að auki felst mikilvægi rannsóknarinnar í pví að halda til haga peirri reynslu og pekkingu sem fyrir liggur á pessu sviði.

\section{Niðurstöður}

Viðmælendurnir sjö eiga pað sameiginlegt að hafa langa reynslu af tölvum og notkun stafrænnar tækni í starfi með börnum í leikskóla og við greiningu gagna komu fram sameiginleg pemu sem marka niðurstöðukaflann. Demun voru fagmennska kennaranna, viðhorf peirra og hvernig peir upplifðu viðhorf annarra til tölvutækni í leikskólastarfi, búnaður og bjargir, áherslur kennaranna á markmið með tölvutækninni í starfinu með börnunum og að lokum er fjallað um áherslur og viðfangsefni kennaranna í leikskólastarfinu með tölvutækni. Vitnað er í orð viðmælenda án pess að aðgreina pá og stundum í pá alla til að sýna samhljóm og áherslur.

\section{Fagmennska kennara}

Greina mátti sambærilega sýn viðmælenda á eigin fagmennsku sem lýsti sér meðal annars í pví að allir vildu peir nota fjölbreytta kennsluhætti og reyna nýjar leiðir í kennslu par sem nýjasta tækni væri notuð í starfinu með börnunum. Flestir kennaranna höfðu notað aðra tækni í starfi með börnunum áður en tölvurnar komu í skólana peirra, svo sem myndbandsupptökur eða hljóðupptökur á snældur eða höfðu persónulega reynslu af stafrænni tækni. Deir nefndu margir að ein forsendan fyrir pví að kennari næði árangri í að vinna með tæknina í leikskólastarfi væri að hann hefði jákvætt viðhorf til upplýsingatækni.

Viðmælendum varð tíðræett um hvað aðgengi að rannsóknum og upplýsingum um pað sem var að gerast á pessu sviði úti í heimi var takmarkað á fyrstu árunum. Deir fótuðu sig sumir án pess að hafa sterkan fræðilegan grunn að standa á annan en pann sem lá undir leikskólafræðum almennt. Viðmælandi orðaði eigin reynslu á pessa leið: „Ég sótti náttúrulega engar hugmyndir til pessa neins staðar, ekkert til í upphafi“ og annar sagði: „Kenningarlegu hugmyndirnar komu seinna, við fundum okkur fræðinga sem pössuðu við okkar áherslur.“ Skortur á rannsóknum eða takmarkað aðgengi að peim gaf kennurum ákveðið svigrúm til að nálgast vinnuna með tölvutæknina á sínum eigin faglegu forsendum en var um leið eitthvað sem kennararnir fundu fyrir að pyrfti að mæta.

\section{Viðhorf}

Viðhorf viðmælenda voru skýr pegar kom að umræðu um kosti snjalltækjanna. Deir sögðu spjöldin handhæg, mögulegt væri að hafa pau sítengd og pau væru einkar barnvæn. Deir nefndu að góður kennari gæeti nýtt tækin á ótal vegu til hagsbóta fyrir börnin en sumir vildu pó minna á að tæknin sem slík væri ekki öll glæný og framandi. Margir möguleikar spjaldtölvunnar væru í boði í öðrum tölvubúnaði og margir kennarar hefðu notað tölvur lengi með góðum árangri. Deir sögðu að almennt væru tölvur einna mest nýttar við sérkennslu. 
Degar viðmælendur litu til baka og lýstu aðstæðum í samfélaginu og leikskólunum á peim tíma pegar fyrsta aðalnámskrá leikskóla (Menntamálaráðuneytið, 1999) tók gildi var margt sem peim pótti mikilvægt. Mikill áhugi var á tölvuvæðingu í samfélaginu almennt og menntakerfinu sérstaklega en á móti kom að mörgum pótti tölvutæknin ekki við hæfi ungra barna. Tölvur voru 1́ örri próun, fjöldi peirra heimila sem átti tölvu óx smám saman og grunnskólar voru margir komnir með tölvur eða tölvuver. Aftur á móti sögðu kennararnir að pað hefði engan veginn pótt sjálfsagt að ung börn umgengjust tölvur, eða eins og einn viðmælenda sagði: „Degar petta [tölvan] kom inn í skólana, pá var ekki ætlast til pess að pað væri fyrir börn. Detta var bara fyrir starfsfólkið.“ Annar viðmælandi tók í sama streng: „Фað pótti ekki til siðs á pessum tíma að börn fengju að koma við svona merkileg tæki.“

Viðmælendur sögðu að í leikskólum hefðu verið uppi efasemdaraddir um hvort leikskólabörn ættu að hafa aðgang að tölvum og að foreldrar hefðu haft áhyggjur af að börnin yrðu of mikið í tölvunni og misstu pá af öðru sem skipti meira máli. Einnig nefndi einn kennarinn hræðslu við tölvufíkn:

Foreldrar höfðu áhyggjur fyrst. Að börnin væru að einangrast í tölvum og voru hræddir við petta af pví að tölvur tengdust nördum og pað tengdist einhverfu og fólki sem kunni ekki félagsleg samskipti. Pannig að við bara purftum að kynna petta virkilega vel.

Af viðtölunum mátti ráða að svipuð sjónarmið væru enn uppi: „Mér finnst jafnvel vera meiri hræðsla við petta í dag ... og foreldrar hafa meiri áhyggjur af bví í hvað börnin komast,“ sagði einn peirra og annar orðaði reynslu sína með pessum hætti:

Detta fer alltaf pennan hring, petta byrjar og er parft og fólk vill, já, fá petta inn og svo ... eftir stutta stund pá eru allir svo hræddir ... að börnin verði háð pessu, hvað pau séu að gera með tölvurnar, að pau fái stirðleika í hnakkann, geri ekki neitt annað og verði bara tölvusjúklingar. Detta fylgir alltaf svona í kjölfarið, finnst mér.

Einn viðmælenda lýsti viðhorfum foreldra í upphafinu á pennan veg: „Ég held að foreldrarnir hafi verið stærsti stuðningsmannahópurinn á pessum tíma. Dað var áhugi hjá foreldrum fyrir pví að fá tölvur ... og pau, held ég, að hafi verið stærsti og jákvæðasti hópurinn á pessum tíma.“ Annar sagði: „,[Viðhorfið] var misjafnt, pessi foreldrahópur virtist vera svona upp til hópa jákvæður en ég heyrði bæði svona efasemdaraddir hjá foreldrum, já, og mínum kollegum, kennurum og síðan hjá peim sem að stjórnuðu málunum hjá bænum." I sumum viðtalanna kom fram að mögulega væru gagnrýnisraddirnar hljóðari núna en ádur. Hvað inntak snertir væri helsti munurinn á umræðunni pá og nú sá að nú væri lítið rætt um tækin sem leið til að jafna aðstöðumun barnanna og minna rætt um aldursviðmið nema í sambandi við skjátíma. Að lokum nefndu sumir kennararnir að bæði áður og nú hefði lítið verið talað um að forritin sem notuð væru í leikskólunum væru mikið til á ensku.

\section{Búnaður og bjargir}

Aðbúnaður og bjargir í skólum voru mismunandi eftir sveitarfélögum og pað kom skýrt í ljós í viðtölunum. Đað tók gjarnan langan tíma að fá nauðsynlegan búnað og aðgengi að neti, eins og sjá má á orðum viðmælenda: „Við fengum práðlaust net 2014 ... Раð að vera með práðlaust net, pað er bylting." Aðrir fengu nettengingu á deildir og staðarnet upp úr aldamótum. Rifjaðar voru upp sögur af fyrstu árunum með tölvunum, par sem snúrur lágu um öll gólf og stundum milli húsa til að ná tengingum eða sambandi. Aðstæður voru í upphafi frumstæðar og pað kostaði fyrirhöfn og oft mikla eftirfylgni að fá einföldustu tæki, hvað pá aukabúnað og kennarar purftu að leggja mikið á sig til að rökstyðja pörfina. Tilhneiging var til að senda úreltan búnað í leikskólana og jafnvel taka burt tæki sem póttu ópörf í leikskóla, svo sem eins og prentara, ljósritunarvélar eða hreinlega tölvurnar sjálfar. Oft kostaði átök að fá nauðsynlegan búnað til að geta unnið með tölvur í starfinu með börnunum og gekk stundum hægt, eins og sést á orðum eins kennarans: 
„Detta hefur verið mikil barátta og kostað mikil leiðindi.“ Kennararnir virtust ekki alltaf hafa mætt skilningi og einn viðmælenda orðaði reynslu sína með pessum hætti: „Við höfum alltaf átt í höggi við kerfisstjóra sem hafa engan skilning á upplýsingatækni í skólastarfi.“

Margt virðist sambærilegt við framkvæmdina pegar tölvurnar komu fyrst inn í leikskólana og síðar pegar spjaldtölvurnar komu og viðmælendur nefndu ýmsa pætti sem peim póttu mikilvægir í pví tilliti. Deir sögðu að pað fylgdi pví mikill kostnaður að tæknivæða skóla, bæði í fjármunum og mannafla, og gagnrýndu að ekki væri alltaf horft nægilega fram á við pegar pað væri gert. Gera pyrfti ráð fyrir fjármunum til að endurnýja tækin, reka pau og afla nauðsynlegra bjarga. Dannig pótti engan veginn sjálfsagt að tölvuvæðingu skóla fylgdu fjármunir til að reka tækin eða til að kaupa nauðsynleg forrit eða jaðartæki. Flestum viðmælenda varð einnig tíðrætt um forrit og sögðu pau gjarnan ekki nægilega góð, vönduð forrit væru einfaldlega dýr og pungur baggi fyrir skólana að kaupa. Einnig voru viðmælendur gagnrýnir á hve markaðurinn hefði verið ráđandi í tæknivæðingu skóla, bæði fyrr og nú, á kostnað ígrundunar eða parfagreiningar innan skólanna. Dað væru gjarnan aðrir en peir sem ættu að nota tækin sem ákveddu hvað væri keypt og pað pætti kennurum óásættanlegt, líta mætti á pað sem ,skólabókardæmi um vond vinnubrögð“. Einnig upplifðu sumir að ekki væri tekið mark á ábendingum peirra eða beiðnum og pví ekki endilega keypt pað sem nýttist peim best; ,,... varðandi innkaup og annað, pað var ekki hlustað á okkur.“ Takmarkanirnar lægju að einhverju leyti í skorti á samráði, samskiptum og sýn á pörfina innan skólanna. Til að mynda kom fram að peir kennarar sem vildu tölvur hefðu átt erfitt með að fá pær á meðan sums staðar hefðu allar deildir fengið tölvur, hvort sem pær voru svo notaðar eða ekki. Slíkt sögðu viðmælendur að gæti hvorki talist hagkvæmt né skynsamlegt. Af viðtölunum má pannig ráða að mikið hafi skort á samráð og samskipti við starfslið skólanna og sýn á pörfina innan hvers skóla fyrir sig.

\section{Markmið með tölvutækni í leikskólastarfi}

Kennararnir voru sammála um að mikilvægur páttur í tölvuvæðingu leikskóla væri að tilgangur og markmið með tölvunotkuninni væru skýr. „Баð er númer eitt að hafa markmið,“ sagði einn viðmælenda og fleiri töldu mikilvægt að kennarar hefðu skýra sýn á hvað nást ætti fram með notkun barnanna á tölvum. Viðmælendum pótti öllum mikilvægt að gerður væri skýr greinarmunur á kennslu á tölvurnar og pví að nota tölvurnar til náms og kennslu í starfinu með börnunum. Deir sögðu tölvurnar og spjöldin vera kennslutæki sem peir notuðu, bæði markvisst og óundirbúið, með fjölbreyttum hætti í leik og starfi. Börnin lærðu á tækin með pví að nota pau við sampætt verkefni og kennsla á tölvurnar sjálfar væri ekki meginmarkmið heldur afleiðing af annarri vinnu. Brot úr viðtölunum endurspegla vel hvernig viðmælendur litu á tækin:

- „bara eins og enn ein skóflan“

- ,við notum petta sem leikfang“

- „eitt verkfæri í viðbót“"

- „sem eitt af kennslutækjunum, eins og litirnir eða jafnvægissláin í salnum“

- „petta væri bara einn af möguleikunum til að læra“

- „eins og blýanturinn eða bara eitthvað“

- „, „petta eru verkfæri til að gera sömu hluti og við höfum alltaf gert“

Einnig lýstu viðmælendur aðgengi barnanna að tölvunum, peir sögðu pað oft hafa verið frjálst og að áhersla hefði frá upphafi verið lögð á að hvetja börnin til samvinnu og samhjálpar við tölvurnar. Sumir kennaranna settu í upphafi tímamörk á viðveru barna í tölvunum en fleiri gerðu pað ekki: „Tölvustofur og mæling á tíma er[u] ekki fyrir börn,“ sagði einn kennarinn pegar vikið var að pessu: 
[Tölvurnar voru] bara eitt af valinu, við lögðum mikla áherslu á að pær væru tvær hlið við hlið, pannig að pað væri samleikur. Đetta væri ekki, pú værir ekki einn í tölvunni, pað gátu tveir valið að vera við hverja tölvu. Pau voru að skiptast á, pau voru í samhliða leik, pannig að pað væri ekki verið að taka af peim samskipti.

Af viðtölunum má ráđa að frumkvöðlarnir litu svo á að tölvunotkun gæti leitt til örvandi samskipta og samskipti barna við tölvurnar haft jákvæð áhrif á nám og proska barnanna. Viðmælendur höfðu fulla trú á að nota mætti tækni til að efla nám og proska barnanna og höfðu, með tímanum, styrkst í peirri vissu að tæknin ætti að eiga sinn sess í starfi leikskóla.

\section{Stafræn tækni í leikskólastarfinu}

Frumkvöðlarnir unnu í upphafi flestir með teikniforrit í skapandi verkefnum með börnunum og margir með ritvinnsluforrit við sögugerð og fleira en einnig leikjaforrit sem ýmist voru sótt til Norðurlandanna eða Ameríku, allt eftir tölvugerð og stýrikerfi. Einn viðmælenda sagði:

Við vorum með tölvur, við vorum með smásjár fyrir tölvurnar og prentara og skanna. Dað var mikill galdur pegar við fengum skanna inn til krakkana. Mér finnst svo mikilvægt að petta sé ekki á skrifstofunni, að petta væri til.

Í upphafinu var flest sem sneri að tölvunum framandi fyrir aðra starfsmenn skólanna og gjarnan voru viðmælendur í hlutverki kennara og stuðningsaðila gagnvart samstarfsfólki sínu: „Рað purfti að læra alla hluti og bara pað að senda tölvupóst. Detta er bara lærdómur.“

Viðmælendum varð tíðrætt um kosti tækninnar og töldu hana bjóða upp á marga og nýstárlega möguleika til að vinna með viðfangsefni af margvíslegum toga í leikskólastarfinu:

Við hugsuðum petta einungis sem tæki til að nota til viðbótar við önnur kennslugögn, skólar höfðu oft verið framarlega í flokki í upplýsingatækni og tækni og petta fannst okkur svona framhald á pví, að hægt væri að lita [á] tölvuskjá eins og á blaði og skrifa eins og á blaði, petta opnaði ýmsa möguleika, og síðar flett upp myndum af dýrum, til dæmis, og leita að nöfnum á vefnum, eins og að vera með bókina. Pannig að við sáum petta bara sem framlengingu eða annað tól til að gera hlutina, stundum á einfaldari hátt, tölvan flækir stundum málin, pað er ekkert sjálfgefıð að hlutirnir gerist á einfaldari hátt. En ég held að petta hafi verið pað sem við sáum fyrir okkur.

Viðmælendur voru sammála um að tölvurnar byðu upp á fjölmarga möguleika og aðspurðir um viðfangsefnin lýstu peir fjölbreytilegri iðju eins og ráða má af töflu 1.

Tafla 1. Helstu viðfangsefni kennaranna í tölvutækni með börnunum

\begin{tabular}{ccccc}
\hline Sköpun & Tákn og mál & Upplifun & Gagnaöflun & Annað \\
\hline Teikning & Málörvun & Ævintýraleg upplifun & Fræðsla & Skráningar \\
Myndlist & Læsi & Skynupplifun & Upplýsingaleit & Sérkennsla \\
Tónlist & Stærðfræði & Afslöppun & Tilraunir & \\
& & Njóta & Rannsóknir & \\
\hline
\end{tabular}

Öllum varð viðmælendunum líka tíðrætt um mikilvægi pess að nota tölvurnar á skapandi hátt, pegar litið var til baka, pegar peir lýstu pví sem peir væru að gera nú um stundir í tölvunum og pegar peir ræddu almennt um notkunarmöguleikana:

[Við] verðum að nota petta á skapandi hátt ... og pá erum við með leiki í pessu til að kenna til dæmis hugtök sem eru mér hugleikin, pað er svo pægilegt að nota pessi tæki til pess að kenna liti, form, tölur og stafi ... en sköpunarpátturinn fer fram pegar við kveikjum á myndvinnsluforriti, ritvinnslu eða förum inn í upplýsingaleit. 
Frumkvöðlarnir töldu pó einnig að snjalltækjanotkunin mætti almennt vera fjölbreyttari og meira skapandi í leikskólum: „Við erum held ég alltof einhæf í notkuninni á pessu í leikskólanum, аð pað skuli ekki vera meira skapandi ... og pá meina ég í öllu starfi, ekki bara í myndlist eða svoleiðis heldur bara skapandi.“ Annar viðmælenda orðaði petta svona:

[Kennarar purfa að] ... gleyma sér í æevintýrinu með börnum. Deir geta notað tölvurnar til pess. Tengt petta við pað sem verið er að gera. Flett upp á sjóræningjafána, kennt börnum að teikna hann, tengja pað við eitthvað sem við hlaupum út til að gera, förum að smíða, sampætt og skapandi.

Degar viðmælendur ræddu innleiðingu snjalltækni í leikskóla síðustu misserin voru flestir sammála pví að hægt hefði verið að læra meira af pví sem pegar hafði verið reynt og gert og pannig hefði mátt komast hjá að falla í sömu gryfjur og í fyrra sinnið. Ekki væri byggt á reynslunni og pekkingunni sem fyrir lægi og oft vantaði upp á að málin væru skoðuð til enda áður en lagt væri upp, ytri markmiðin væru óljós og jafnvel engin. Einn viðmælenda sagði: „Mér finnst að menn hafi farið aftur á byrjunarreit.“ Annar tók undir petta og sagði: „Mér fannst að samstarfsmenn mínir hefðu einfaldlega ekkert lært.“ Fleiri dæmi má nefna um sambærilega hugsun: „[Í] pessari spjaldtölvubyltingu finnst [mér] eins og menn hafi byrjað á núllpunkti." Flestir viðmælendur töldu að spjaldtölvuvæðing skóla síðustu árin væri ekki alltaf nægilega markviss, hún tæki lítið mið af samráði eða líkum á pví að búnaðurinn kæmi að góðum notum: „Mér finnst menn [sveitarfélögin] bara voðalega lítið vita hvað peir ætla að gera við petta allt saman“ eða eins og annar viðmælenda sagði: „,.. ég held аð pað purfi pínu samt, sko, að ræða hlutina og pú veist, hvernig á að nota petta?“ ' Priðji kennarinn orðaði sömu gagnrýni á pennan veg: „Detta er bara tæki, pú ferð ekki fyrst út í skúr og nærð pér í hamar og ákveður svo hvað pú ætlar að negla pegar pú kemur inn." Kennararnir kölluðu eftir samráði og bentu á að margt mætti læra af pví sem pegar hefði verið unnið í leikskólum á pessum vettvangi.

\section{Umræða og lokaorð}

Kennararnir sem tóku pátt í viðtölunum voru allir hlynntir notkun stafrænnar tækni í leikskólastarfi enda var pað ein forsendan fyrir pátttöku í rannsókninni. Í raun má segja að peir séu talsmenn tækninnar sem hluta af starfi leikskóla og hafi par með sterkar skoðanir á flestum peim páttum sem að málefninu snúa. Vinna peirra með tæknina endurspeglar í öllum tilvikum afstöðu peirra til tækninnar og fellur vel að gildandi aðalnámskrá leikskóla (Menntaog menningarmálaráđuneytið, 2011) par sem sampætting námssviða, leikur sem námsleið og skýr markmiðssetning eru lykilpættir. Anna Magnea Hreinsdóttir (2004) segir að starfsmenn leikskóla hafi almennt jákvæð viðhorf til stafrænnar tækni og möguleika hennar í leikskólastarfi og niðurstöður Önnu sýna að peir trúa á gagnsemi hennar til að efla nám barnanna ef hún er notuð markvisst og viðfangsefnin eru valin af kostgæfni. Allt tónar petta vel við niðurstöður pessarar rannsóknar en í báðum tilvikum var talað við fólk sem pegar notaði stafræna tækni í starfinu.

Niðurstöður draga fram jákvæða sýn viðmælenda á tölvur og snjalltækni í leikskólastarfi en gagnstæð viðhorf eru peim ekki ókunnug, hvorki frá pví fyrr á árum né nú um stundir. Mikilvægt er að rifja upp að kennarar eru ekki á einu máli um hvort tæknin bæti námsárangur barna samanber niðurstöður Dhir o.fl. (2013). Raddir peirra sem efast purfa einnig að heyrast og mikilvægt er að vera gagnrýninn á alla beitingu tækni í skólunum. Velta má fyrir sér hvort gagnrýni og neikvæð afstaða til tækninotkunar í leikskólum eigi rætur í vantrú á að tölvutækni henti í leikmiðuðu námsumhverfi (Palmer, 2015) eða hreinlega efasemdum um að tæknin leiði af sér nám (Northrop og Killeen, 2013) eða proska. Hvort heldur sem er geta viðhorf af pessu tagi valdið pví að litið er á tölvutæknina sem varasama og jafnvel hættulega. Hún tekur pá tíma frá öðrum viðfangsefnum sem eru talin mikilvæg og pað er ljóst að ræða parf efasemdirnar og takast á við álitamálin, bæði innan skóla og utan. Í niðurstöðum rannsóknarinnar kom fram reynsla af bæði jákvæðum og neikvæðum viðhorfum foreldra en umræða og fræðsla getur verið ein leið til 
að veita foreldrum skýrari sýn á gildi tölvutækni í leikskólastarfi. Sú umræða mætti snúast annars vegar um muninn á pví að nota tækni í skólaumhverfi eða nota snjalltæki sem afpreyingu heima eða hins vegar hvernig pversagnir í niðurstöðum rannsókna geta verið vegna pess að verið er að rannsaka ólíka pætti eða viðfangsefni.

Á svörum má sjá að kennararnir skilgreina tölvuna sem verkfæri eða leikfang fyrir börnin og pegar peir lýstu aðferðum sínum um pað leyti sem fyrst var farið að vinna með tölvur í starfinu með börnunum kom pessi áhersla ítrekað fram. Tölvan hefði frá upphafi verið í leikrými barnanna og umgengni við hana í flestum tilvikum sambærileg og átti við um aðra leikmuni eða viðfangsefni á peim tíma. Með öðrum orðum var litiðá tölvunotkun sem hluta af leik barna. Frumkvöðlarnir lögðu mikla áherslu á markmið og markvisst starf og áhersla kennara á skýran tilgang á samhljóm í fleiri rannsóknum (s.s. Northrop og Killeen, 2013). Bird og Edwards (2015) hafa minnt á að til að leikskólakennarar almennt noti tæknina 1 auknum mæli purfi að sýna peim fram á hvernig tæknin getur virkað til náms í gegnum leik. Yadav og Chakraborty (2018) taka í sama streng. Viðmælendur Önnu Magneu Hreinsdóttur (2004) virtust hafa skýra sýn á pessi tengsl og Kristín Norðdahl og Svala Jónsdóttir (2005) komust í sinni rannsókn að peirri niðurstöðu að tölvutækni væri nýtt með fjölbreyttum hætti í leikskólum, til náms, samskipta og við upplýsingaleit. Sameiginlegur práður í starfsaðferðum frumkvöðlanna pá og nú var að nota stafrænu tæknina sem leikefni og leið að tilteknum kennslumarkmiðum sem geta verið fjölbreytt og snúið að mörgum proska- og námspáttum.

Samskipti barnanna, nám meðjafningjum og samvinna eru alltáherslupættirístarfi frumkvöðlanna sem á bak við viðtölin stóðu. Detta má sjá á pví hve tíðræett peim varð um mikilvægi samskipta á milli barna við tölvurnar. Marsh (2010) taldi einmitt að stafræn tækni gæti haft jákvæð áhrif á samskipti og í sama streng taka Kristín Norðdahl og Svala Jónsdóttir (2005). Vinnubrögð af pessu tagi vinna einnig sterklega á móti goðsögnum um að tölvur séu einangrandi og hafi slæm áhrif á félagsproska svo vitnað sé til rannsóknar Plowman og McPake (2013) eða að tölvutækni sé best nýtt við skipulagningu og undirbúning kennara, eins og kom fram í rannsókn Masoumi (2015). Fleira í viðtölunum rímar við rannsóknir annars staðar í heiminum, svo sem gagnrýni viðmælenda á gæði forrita en Yilmaz (2015) vill meina að góð forrit og samskipti á milli barnanna við tölvurnar sé ein forsenda náms í gegnum tölvutækni. Gildi samvinnu við verkefni kom einnig fram í rannsókn Butler og Walton (2013) sem sögðu samvinnuna auka úthald og ánægju, prautseigju og áhuga.

Hluti af reynslusögu viðmælenda er að peir voru í pví hlutverki að veita samstarfsfólki sínu stuðning og leiðsögn í tæknimálum. Detta vekur upp spurningar um mikilvægi pess að finna leiðir til að styðja við pá kennara sem vilja stíga fyrstu skrefin eða efla sig á pessu sviði. Sjálfstraust kennara ræður miklu um hvernig, eða jafnvel hvort, peir nota tæknina í starfi ef rifjaðar eru upp niðurstöður Blackwell o.fl.(2014). Kennarar purfa að hafa gott aðgengi að fræðslu og pjálfun í stafrænni tækni í skólastarfi að styðjast við í sinni starfspróun, hið minnsta peir sem áhuga hafa en petta hafa Kerckaert, Vanderlinde og van Braak (2015) einmitt bent á. Í sama streng tekur Fjóla Dorvaldsdóttir (2018) pegar hún segir kennara kalla eftir ráđgjöf. Nikolopoulou og Gialamas (2015) telja að pjálfun kennara skipti sköpum ef efla eigi tölvutækni sem pátt í starfi leikskóla og án efa má nýta pá kennara sem hafa farsæla reynslu og jákvætt viðhorf til tækninnar við pjálfun og uppfræðslu annarra kennara. Kennararnir í rannsókninni kalla líka eftir meira og péttara samráði peirra sem stefnumótunar- og peningavaldið hafa við skólana og pá sem eiga að nota búnaðinn við stefnumótun og innkaup. Sömu niðurstöðu fengu Anna Magnea Hreinsdóttir (2004) og Kristín Norðdahl og Svala Jónsdóttir (2005). Kennararnir í rannsókninni lýsa langri reynslu af að hafa ekki fjármagn til að kaupa tæki og forrit og síðar til að halda peim við, sá vandi er vel pekktur annars staðar frá eins og kom fram í rannsókn Thorpe o.fl. (2015). Viðmælendur vilja meira samráð og pegar sum sveitarfélög leggja töluverða fjármuni í að tæknivæða leikskóla er vert að draga fram tækifærin sem liggja í samráði. 
Niðurstöður pessarar rannsóknar tóna að mörgu leyti við niðurstöður NámUST-rannsóknarinnar sem kynnt er hér framar og í raun kemur pað ekki á óvart. Leiða má líkur að pví að einhverjir viðmælenda hér séu peir sömu og í NámUST-rannsókninni eða hafi í pað minnsta starfað í skólum par sem sú rannsókn fór fram. Að lokum er áréttað að tölvutæknin sjálf gerir ekki gagn ein og sér, pað eru kennararnir sem nota hana í starfi sem leika lykilhlutverk pegar nota á tækni í skólastarfi. Hjá peim liggur pekkingin og reynslan til að koma vinnu með stafræna tækni í sem bestan farveg en til að peir geti unnið sitt starf sem best purfa peir gott svigrúm til próunar. Enn skortir rannsóknir á pessu sviði, rannsóknir sem snúa að snjalltækni í tengslum við nám í gegnum leik, rannsóknir á tengslum tækni við námsárangur og alhliða proska, rannsóknir og próunarstarf sem leiða í ljós í hvaða viðfangsefnum tæknin hentar og hvar hún hentar ekki í starfi leikskóla.

\section{Digital technology in preschools. From the viewpoint of pioneers}

In 1999 National Curriculum Guide for Preschools (Menntamálaráðuneytið [Ministry of Education], 1999) was published, which promoted computers as part of the preschool curriculum. The main purpose given was educational equality, the aim was to ensure that all children had access to computers regardless of their family situation. Hence, children with no access to computers at home would be able to learn about them and technology in school. When the curriculum came into force, some preschools had already introduced computers as a teaching tool. After the publication of the curriculum, an increasing number of preschools took the steps needed to introduce computers. It could be said that computers are not new in Icelandic preschools; however, it is important to remember the beginning. It is essential to learn from history, especially now with the second wave of technological education in preschools at its peak and 21th century skills in the making.

Smart technology is becoming a stronger aspect of the lives of young children and they have access to technology earlier than ever before. Schools have embraced the new technology and it has widely become part of the preschool curriculum. In that light it is of vital importance to look at the impact of technology on the lives and learning of young children. Studies have been conducted that show both the positive impact of technology on young children's learning and its limitations, or even harmfulness. This research emphasises the development of computers as part of preschool education over the past twenty years. The aim of the research is to investigate the development of computers as an aspect of the preschool curriculum over the past twenty years. The point of departure in this paper is the introduction of computers in the 1999 National Curriculum Guide (Menntamálaráðuneytið [Ministry of Education], 1999), progressing toward the release of smart technology in recent years.

Data was gathered by interviews with seven pioneers in the use of technology in preschool education. The focus was on their experience, views and beliefs. All participants were initiators of the introduction of computers in preschools both before and following the publication of the National Curriculum Guide for Preschools in 1999 and they are all still using computers and technology with preschool children today. Half-open questions were asked, concentrating on two main aspects. The subject focused on the use of computers in preschool teaching, emphasising preschool education and work with young children. The first set of questions dealt with the technological development of preschools around the year 1999 and then similar questions were asked concerning the introduction of tablets and smart toys. Additionally, questions were put forward about the initial implementation of computers into the preschool curriculum, compared with their experiences of today, and the lessons they had learnt from the whole process. The interviews, which lasted 60-90 minutes, were transcribed and analysed in themes. 
The results indicate that significant experience has been gained since the introduction of computers more than twenty years ago. There have been technological developments in preschools and technological devices have been used in a variety of ways in children's education and curriculum. The interviewees consider it important to clearly distinguish between teaching children to use technology and how teachers use technology when working with children. They say that computers and tablets are the teaching tools they use, both purposefully and spontaneously, in a variety of ways. Digital literacy comes from using computers in various ways, so teaching children to use a computer is not the main goal but rather seen as a byproduct of other educational work. It is clear, that the views of the interviewees are mostly similar, even though their teaching methods may vary when it comes to using new technologies. Most of the participants had personal experience using technology before they introduced it to preschool children; some had worked with different kinds of technologies with children before computers were formally introduced as part of the preschool curriculum.

Introducing digital technology to the preschool curriculum was not always an easy journey. Many teachers had difficulty getting enough equipment or even the correct equipment needed. In some cases, this issue has remained. The teachers are critical of the preschool system and believe that more lessons could be learned from what has already been gained in the field of digital technology in preschools. They also claim that there is lack of purposeful goals regarding resources. The teachers want to focus on targets, creativity and the integration of digital technological use, both in methods and subjects. They also want to use varied teaching methods and seek out new ways of teaching. They believe that a positive attitude towards technology is one of the prerequisites for the teacher to succeed in working with both digital and other technology in preschools.

Key words: Preschool, computers, digital technology, pioneers

\section{Um höfund}

Anna Elísa Hreiðarsdóttir (annaelisa@unak.is) er lektor við kennaradeild Háskólans á Akureyri. Hún brautskráđist frá Fósturskóla Íslands árið 1990 sem fóstra, lauk B.Ed.gráđu frá Háskólanum á Akureyri árið 2000 og M.Ed.-prófi sex árum síđar frá sama skóla. Anna Elísa starfaði um árabil sem leikskólastjóri, aðstoðarleikskólastjóri og deildarstjóri í leikskóla. Rannsóknir hennar og próunarverkefni snúa meðal annars að foreldrasamstarfi, jafnrétti, starfi með elstu börnum leikskólans og tölvum og tækni í leikskólastarfi.

\section{About the author}

Anna Elísa Hreiðarsdóttir (annaelisa@unak.is) is an assistant professor at the University of Akureyri. She graduated as a preschool teacher in 1990, holds a B.Ed. degree in preschool teaching (2000) and an M.Ed. degree (2006). Anna Elísa has worked as a preschool teacher and a head teacher. Her research focuses on partnership with families in preschools, professional work with five-year-old children, gender studies and computers and technology in preschools. 


\section{Heimildir}

Akureyrarbær. (2003, 14. október). Frábær árangur leikskólans Iðavallar. Sótt af https://www.akureyri.is/is/ frettir/frabaer-arangur-leikskolans-idavalla

Anna Magnea Hreinsdóttir. (2004). Tóti var einn í Tölvulandi, á tölvuspilið var snjall. Athugun á tölvunotkun leikskólabarna. Netla - Veftímarit um uppeldi og menntun. Sótt af http://netla.hi.is/greinar/2004/004/ index.htm

Anna Magnea Hreinsdóttir, Kristín Norðdahl og Svala Jónsdóttir. (2005). Tölvuvœðing leikskóla. Miðar henni? Staða upplýsinga- og samskiptatakni í leikskólastarfi á Íslandi [skýrsla NámUST]. Reykjavík og Akureyri: Kennaraháskóli Íslands, Háskólinn á Akureyri og Háskólinn í Reykjavík.

Bingimlas, K.A. (2009). Barriers to the successful integration of ICT in teaching and learning environments: A review of the literature. Eurasia Journal of Mathematics, Science E Technology Education, 5(3), 235-245. doi:10.12973/ejmste/75275

Bird, J. og Edwards, S. (2015). Children learning to use technologies through play: A digital play framework. British Journal of Educational Technology, 46(6), 1149-1160. doi:10.1111/bjet.12191

Blackwell, C. K., Lauricella, A. R. og Wartella, E. (2014). Factors influencing digital technology use in early childhood education. Computers \& Education, 77, 82-90. doi:10.1016/j.compedu.2014.04.013

Brinkmann, S. og Kvale, S. (2015). Interviews: Learning the craft of qualitative research interviewing (3. útgáfa). Los Angeles: Sage.

Broemmel, A. D., Moran, M. J. og Wooten, D. A. (2015). The impact of animated books on the vocabulary and language development of preschool-aged children in two school settings. Early Childhood Research and Practice, 17(1). Sótt af http://ecrp.uiuc.edu/v17n1/broemmel.html

Butler, L. P. og Walton, G. M. (2013). The opportunity to collaborate increases preschoolers' motivation for challenging tasks. Journal of Experimental Child Psychology, 116(4), 953-961. doi:10.1016/j.jecp.2013.06.007

Capacent. (2014). Skýrsla starfshóps um upplýsingatakni í skólastarfi - tillögur til úrbóta. Reykjavík: Höfundur.

Chen, J. og Chang, C. (2006). Testing the "whole teacher" approach to professional development: A study of enhancing early childhood teachers' technology proficiency. Early Childhood Research E Practice, 8(1). Sótt af http://ecrp.uiuc.edu/v8n1/chen.html

Cherrington, S., Oldridge, L., Green,V., Dalli, C., Davidson, S., Glasgow, A. .. Wansbrough, D. (2009). Evaluation of the Early childhood education information and communication technology professional learning programme. Nýja-Sjáland:Victoria University of Wellington.

Couse, L. J. og Chen, D. W. (2014). A tablet computer for young children? Exploring its viability for early childhood education. Journal of Research on Technology in Education, 43(1), 75-98. doi:10.1080/15391523 2010.10782562

Cristia,A. og Seidl,A. (2015). Parental reports on touch screen use in early childhood. PLoS One 10(6). doi:10.1371/ journal.pone.0128338

Dagskrá UT99. (1999). Ráđstefna um upplýsingatækni í skólastarfi haldin af menntamálaráđuneytinu í samstarfi við Skýrslutæknifélag Íslands í Menntaskólanum í Kópavogi 26.-27. febrúar 1999.

Dhir, A., Gahwaji, N. M. og Nyman, G. (2013). The role of the iPad in the hands of the learner. Journal of Universal Computer Science, 19(5), 706-727.

Dietze, B. og Kashin, D. (2013). Shifting views: Exploring the potential for technology integration in early childhood education programs. Canadian Journal of Learning and Technology, 39(4), 1-13.

Edwards, S. (2013). Digital play in the early years: A contextual response to the problem of integrating technologies and play-based pedagogies in the early childhood curriculum. European Early Childhood Education Research Journal, 21(2), 199-212. doi:10.1080/1350293X.2013.789190

Erasmus+. (e.d.). Verðlaun og viðurkenningar. Sótt af https://www.erasmusplus.is/menntun/etwinning/verdlaun-og-vidurkenningar/

Erasmus+. (2016, 8. nóvember). Leikskólinn Holt hlýtur Evrópuverðlaun eTwinning. Sótt af https://www.erasmusplus.is/um/frettir/leikskolinn-holt-hlytur-evropuverdlaun-etwinning 
Ernest,J. M., Causey, C., Newton, A. B., Sharkins, K., Summerlin, J. og Albaiz, N. (2014). Extending the global dialogue about media, technology, screen time, and young children. Childhood Eduation, 90(3), 182-191. doi:10.1080/00094056.2014.910046

Ertmer, P. A. og Ottenbreit-Leftwich, A. (2013). Removing obstacles to the pedagogical changes required by Jonassen's vision of authentic technology-enabled learning. Computers \& Education, 64(1), 175-182. doi:10.1016/j.compedu.2012.10.008

Fessakis, G., Gouli, E. og Mavroudi, E. (2013). Problem solving by 5-6 years old kindergarten children in a computer programming environment: A case study. Computers \& Education, 63(1), 87-97. doi:10.1016/j. compedu.2012.11.016

Fjóla Dorvaldsdóttir. (2018). Fikt. Námsvefur um upplýsingatakni fyrir kennara í leikskóla og á yngsta stigi grunnskóla (óútgefin meistararitgerð). Sótt af http://fikt.kopavogur.is/wp-content/uploads/sites/15/2018/05/ Fjóla-Porvaldsdóttir.pdf

Guðrún Alda Harðardóttir. (2001). IKT - från förskola til universitet. Reggio fréttir 1(3), 7-10.

Helga Jónsdóttir. (2013).Viðtöl í eigindlegum og megindlegum rannsóknum. Í Sigríður Halldórsdóttir (ritstjóri), Handbók í aðferðafraði rannsókna (bls. 137-153). Akureyri: Háskólinn á Akureyri.

Hoffman, J. L. og Paciga, K.A. (2014). Click, swipe, and read: Sharing e-books with toddlers and preschoolers. Early Childhood Education Journal, 42(6), 379-388. doi:10.1007/s10643-013-0622-5

Hoffman, E. S., Park, E. og Lin, M. G. (2015). Beyond professional development:A case study of implementing iPads in early childhood education. Í D. Slykhuis og G. Marks (ritstjórar), Proceedings of society for information technology and teacher education international conference 2015 (bls. 2008-2015). Chesapeake, VA: Association for the Advancement of Computing in Education (AACE).

Holloway, D., Green, L. og Livingstone, S. (2013). Zero to eight. Young children and their internet use. London: LSE, EU Kids Online.

Hsin, C., Li, M. og Tsai, C. (2014). The influence of young children's use of technology on their learning: A review. Educational Technology \& Society, 17(4), 85-99. http://www.jstor.org/stable/jeductechsoci.17.4.85

Karl Jeppesen og Svala Jónsdóttir. (2006a). Leikskólinn Iðavöllur. Upphafið. Upplýsingatekni i leikskóla 1 [heimildamynd]. Reykjavík: NámUST og Rannsóknarstofnun KHÍ.

Karl Jeppesen og Svala Jónsdóttir. (2006b). Leikskólinn Iðavöllur. Notkun takni. Upplýsingatækni í leikskóla 2 [heimildamynd]. Reykjavík: NámUST og Rannsóknarstofnun KHÍ.

Karl Jeppesen og Svala Jónsdóttir. (2006c). Bifröst, brú milli heima. Upplýsingatcekni i leikskóla 3 [heimildamynd]. Reykjavík: NámUST og Rannsóknarstofnun KHÍ.

Kerckaert, S., Vanderlinde, R. og van Braak, J. (2015). The role of ICT in early childhood education: Scale development and research on ICT use and influencing factors. European Early Childhood Education Research Journal, 23(2), 183-199. doi:10.1080/1350293X.2015.1016804

Kjartan Ólafsson., Livingstone, S. og Haddon, L. (2014, september). Children's use of online technologies in Europe. A review of the European evidence base. London: LSE, EU Kids Online.

Konca, A. S., Ozel, E. og Zelyurt, H. (2016). Attitudes of preschool teachers towards using information and communication technologies (ICT). International Journal of Research in Education and Science, 2(1), 10-15. doi:10.21890/ijres.21816

Kópavogsbær. (2013). Stefna Kópavogsbajar í upplýsingatakni i leikskólum. Sótt af https://www.kopavogur.is/ static/files/Leikskolar/stefna_kopavogsbaejar_i_upplysingataekni_i_leikskolum.pdf

Kristín Norðdahl og Svala Jónsdóttir. (2005). Notkun upplýsinga- og samskiptatækni í sex leikskólum. Netla - Veftímarit um uppeldi og menntun. Sótt af http://netla.hi.is/greinar/2005/018/index.htm

Lahmar, J., Taylor, M., Marsh, J., Jakobsdóttir, S., Velicu, A., Arnseth, H. C. ... Thorsteinsson, G. (2017). Makerspaces in the early years: Current perceptions and practices of early years practitioners, library and museum educators and makerspace staff. University of Sheffield: MakEY Project.

Lindahl, M. G. og Folkesson, A. (2012). ICT in preschool: Friend or foe? The significance of norms in a changing practice. International Journal of Early Years Education, 20(4), 422-436. doi:10.1080/09669760.2 012.743876 
Liu, X. (2015). Early childhood teachers' perceived barriers to ICT integration in teaching: A survey study in Mainland China. Journal of Computers in Education, 2(1), 61-75. doi:10.1007/s40692-014-0025-7

Livingstone, S., Görzig, A. og Kjartan Ólafsson, (2011). Disadvantaged children and online risk. Report. London: LSE, EU Kids Online.

Lynch, J. og Redpath, T. (2014). "Smart” technologies in early years literacy education: A meta-narrative of paradigmatic tensions in iPad use in an Australian preparatory classroom. Journal of Early Childhood Literacy, 14(2), 147-174. doi:10.1177/1468798412453150

Marsh, J. (2010). Young children's play in online virtual worlds. Journal of Early Childhood, 8(1), 23-39. doi:10.1177/1476718X09345406

Marsh, J., Plowman, L., Yamada-Rice, D., Bishop, J. og Scott, F. (2016). Digital play: a new classification. Early Years. An International Research Journal, 36(3), 242-253. Sótt af http://eprints.whiterose. ac.uk/96760/22/5-24-2016_Digital pl.pdf

Masoumi, D. (2015). Preschool teachers' use of ICTs: Towards a typology of practice. Contemporary Issues in Early Childhood, 16(1), 5-17. doi:10.1177/1463949114566753

McKenney, S. ogVoogt, J. (2010). Technology and young children: How 4-7 year olds perceive their own use of computers. Computers in Human Behavior, 26(1), 656-664. doi:10.1016/j.chb.2010.01.002

Menntamálaráðuneytið. (1985). Uppeldisáctlun fyrir dagvistarheimili. Markmið og leiðir. Reykjavík: Höfundur.

Menntamálaráðuneytið. (1993). Uppeldisáatlun fyrir leikskóla. Markmið og leiðir. Reykjavík: Höfundur.

Menntamálaráđuneytið. (1999). Aðalnámskrá leikskóla 1999. Reykjavík: Höfundur.

Mennta- og menningarmálaráđuneytið. (2011). Aðalnámskrá leikskóla 2011. Reykjavík: Höfundur.

Miðstöð skólapróunar. (e.d.). Skýrslur 2018. Sótt af https://www.msha.is/is/moya/page/skyrslur-2018

Neumann, M. M. og Neumann, D. L. (2014). Touch screen tablets and emergent literacy. Early Childhood Education Journal, 42(4), 231-239. doi:10.1007/s10643-013-0608-3

Nikolopoulou, K. og Gialamas,V. (2015). ICT and play in preschool: Early childhood teachers' beliefs and confidence. International Journal of Early Years Education, 23(4), 409-425. doi:10.1080/09669760.2015.1078727

Nilsen, M., Lundin, M., Wallerstedt, C. og Pramling, N. (2018). Evolving and re-mediated activities when preschool children play analogue and digital memory games. Early Years. An International Research Journal, 38(1). doi:10.1080/09575146.2018.1460803

Northrop, L. og Killeen, E. (2013). A framework for using iPads to build early literacy skills. Reading Teacher, 66(7), 531-537. doi:10.1002/TRTR.1155

Orrin, M.T. og Olcese, N. R. (2011). Teaching and learning with iPads, ready or not? Techtrends, 55(6), $42-48$. doi:10.1007/s11528-011-0540-6

Palaiologou, I. (2016). Children under five and digital technologies: Implications for early years pedagogy. European Early Childhood Education Research Journal, 24(1), 5-24. doi:10.1080/1350293X.2014.929876

Palmer. S. (2015). Toxic childhood: How the modern world is damaging our children and what we can do about it. Orion: London.

Plowman, L. og McPake, J. (2013). Seven myths about young children and technology. Childhood Education, 89(1), 27-33. doi:10.1080/00094056.2013.757490

Preradovic, N. M., Lesin, G. og Voras, D. (2016). Introduction of digital storytelling in preschool education: A case study from Croatia. Digital Education, 30, 94-105.

Segers, E. og Verhoeven, L. (2005). Long-term effects of computer training of phonological awareness in kindergarten. Journal of Computer Assisted Learning, 21(1), 17-27. doi:10.1111/j.1365-2729.2005.00107.x

Shawareb, A. (2011). The effects of computer use on creative thinking among kindergarten children in Jordan. Journal of Instructional Psychology, 38(4), 213-220.

Skóla- og frístundasvið Reykjavíkurborgar. (2017). Upplýsingatcekni i leikskólastarfi: Skýrsla starfshóps. Sótt af https://reykjavik.is/sites/default/files/ymis_skjol/skjol_utgefid_efni/130_5.1_ut_leikskolar_nov2017.pdf

Thorpe, K., Hansen, J., Danby, S., Zaki, F. M., Grant, S., Houen, S. .. Given, L. M. (2015). Digital access to knowledge in the preschool classroom: Reports from Australia. Early Childhood Research Quarterly, 32, 174-182. doi:10.1016/j.ecresq.2015.04.001 
Torfi Hjartarson. (1999). Kennslustofa framtíðar. Tölvumál, 24(2), 12-13. Sótt af https://timarit.is/view_ page_init.jsp?pageId=2364673

Torfi Hjartarson og Svava Pétursdóttir. (í prentun). Förskolans digitalisering på Island: En resa som kräver mod, tid och stöd! Í K. Holmberg, A. Lagergren, Torfi Hjartarson og E. Böen (ritstjórar), Lek och lärande med digitala verktyg i nordiska förskolor: Erfarenheter från två Nordplus-projekt 2015-2019. Nordplus á vegum Norrænu ráðherranefndarinnar.

$\mathrm{Vu}, \mathrm{P}$. (2015). What factors affect teachers using the iPads in their classroom? Issues and Trends in Educational Technology, 3(1), 1-15.doi:10.2458/azu_itet_v3i1_vu

Wood, E., Specht, J., Willoughby, T. og Mueller, J. (2008). Integrating computer technology in early childhood education environments: Issues raised by early childhood educators. The Alberta Journal of Educational Research, 54(2), 210-226.

Yadav, S. og Chakraborty, P. (2018). Smartphone apps can entertain and educate children aged two to six but should be used with caution. Acta Paediatrica, 107(10). doi:10.1111/apa.14435

Yilmaz, R. M. (2015). Educational magic toys developed with augmented reality technology for early childhood education. Computers in Human Behavior, 54, 240-248. doi:10.1016/j.chb.2015.07.040

Yurt, Ö. og Cevher-Kalburan, N. (2011). Early childhood teachers' thoughts and practices about the use of computers in early childhood education. Procedia Computer Science, 3(1), 1562-1570. doi:10.1016/j. procs.2011.01.050

Pórólfur Dórlindsson og Porlákur Karlsson. (2013). Úrtök og úrtaksaðferðir í megindlegum rannsóknum. Í Sigríður Halldórsdóttir (ritstjóri), Handbók i aðferðafrææi rannsókna (bls. 113-136). Akureyri: Háskólinn á Akureyri.

Anna Elísa Hreiðarsdóttir (2019).

Stafræn tækni í leikskólastarfi: Sjónarhorn frumkvöðla

Netla - Veftímarit um uppeldi og menntun. Menntavísindasvið Háskóla Íslands.

Sótt af http://netla.hi.is/serrit/2019/menntun_barna_leik_grunn/08.pdf

DOI: https://doi.org/10.24270/serritnetla.2019.40 